(C) 1984. The Genetical Society of Great Britain

\title{
HOMOMORPHIC SEX CHROMOSOMES IN THE LACERTID LIZARD TAKYDROMUS SEXLINEATUS*
}

\author{
E. OLMO,* O. COBROR,* A. MORESCALCHI† AND G. ODIERNA* \\ Institute of Histology and Embryology, University of Naples, via Mezzocannone, \\ 8, 80134, Naples Italy.* Institute of Comparative Anatomy, University of Genoa, \\ via Balbi, 5, 16126, Genoa, Italy. $\dagger$
}

Received 20.xii.83

\section{SUMMARY}

A new case of female heterogamety has been described in Takydromus sexlineatus. In this species the W-chromosome has the same morphology as the Z-chromosome, but differs from it in being heterochromatic and C-banding positive.

This situation is similar to that found in some snakes, and is considered by some investigators as a primitive step in the differentiation of sex chromosomes. This suggests that the mechanisms involved in sex chromosomes differentiation in lizards may be the same as those suggested for snakes.

\section{INTRODUCTION}

Morphologically differentiated sex chromosomes have been reported in 13 of the 53 lacertid species studied so far, although most of the described reports seem to be rather doubtful. Many species possess a female heterogamety of the $\mathrm{ZZ/ZW}$ type where the $\mathrm{Z}$-chromosome is equal in size to the last pair of macro-autosomes, while the W-chromosome is a microchromosome (Kupriyanova, 1968; Gorman, 1969; Ivanov et al., 1973; Ivanov and Fedorova, 1973; Bhatnagar and Yoniss, 1976; Darevsky et al., 1978; De Smet, 1981). In Lacerta vivipara, instead, Chevalier (1969) and Chevalier et al., (1979) described female heterogamety of the $\mathrm{Z}_{1} \mathrm{Z}_{1} \mathrm{Z}_{2} \mathrm{Z}_{2} / \mathrm{Z}_{1} \mathrm{Z}_{2} \mathrm{~W}$ type, where the $\mathrm{W}$-chromosome is metacentric and is probably derived from the fusion of two non-homologous acrocentric chromosomes.

The present paper describes a new case of sex chromosomes in the lacertid lizard Takydromus sexlineatus, where the two homologues do not differ in size and shape, but show different staining by means of the $C$-banding technique.

\section{Materials and methods}

We studied the chromosomes of 3 specimens of Takydromus sexlineatus which were purchased from an animal dealer, and were collected in Thailand.

The animals were treated with colcemid $(0.1 \mathrm{ml} / 10 \mathrm{gr}$ body weight $)$ for $18 \mathrm{~h}$, and then sacrificed.

The chromosome preparations were made by both air-drying and squashing procedures, after fixation with 3:1 methanol-acetic acid. 
The C-banding technique of Sumner (1972) was used with the following modifications: a) the $\mathrm{BaOH}$ treatment was performed at temperatures ranging from $55^{\circ} \mathrm{C}$ to $65^{\circ} \mathrm{C}$ for $5^{\prime}-10^{\prime}$; b) following the $\mathrm{BaOH}$ the slides were briefly rinsed in $0.2 \mathrm{~N} \mathrm{HCl}$; c) finally the slides were stained both with Giemsa for $10^{\prime}$ or with acetic orcein (Darlington and LaCour, 1969) for $5^{\prime}$. In this connection, several observations by one of us (G. Odierna) showed that both stains bring about the same banding pattern.

\section{RESUlts AND Discussion}

All of the Takydromus sexlineatus specimens investigated exhibit a typical lacertid karyotype, equal to that of other species of the genus, with 36 acrocentric macrochromosomes and 2 microchromosomes (Gorman, 1973; Bickham, 1983).

In all females studied by means of the C-banding technique, one of the smallest macrochromosomes appears completely and intensely stained, whereas the homolog is unstained, like the other chromosomes of the complement (plate 1). This has been observed in all the slides examined. On the contrary, in both mitoses and meioses in the male the homologues of the same pair appear to be C-banding negative (plate 2).

This result indicates female heterogamety in Takydromus sexlineatus, where the W-chromosome is morphologically like the Z-chromosome, but differs from it being completely heterochromatic and $\mathrm{C}$-banding positive.

Though it is impossible to distinguish clearly the different pairs of homologs in lizards, it is noteworthy that, in Takydromus, sex chromosomes appear to be as long as those of the other lizards with differentiated sex chromosomes, particularly of Lacerta vivipara.

A situation like that of Takydromus has not been described so far in any other lizard, and is similar to that found in some species of colubrid snakes by Ray-Chaudhury et al. (1971) and Singh et al. $(1976,1980)$.

Singh et al., $(1976,1980)$ demonstrated that the heterochromatinisation of the W-chromosome in several snakes is correlated, at least in part, to the accumulation of a specific sex-linked satellite-DNA. It is possible that there is also a W-linked highly repetitive DNA in Takydromus (and presumably also in other lizards) since the positive C-banding is known to depend on the presence of highly repetitive DNA sequences, often having the characteristics of satellite-DNA (John and Miklos, 1979).

The presence of homomorphic sex chromosomes, differing from one another only in the degree of heterochromatinisation and in stainability with the C-banding method, is considered to be early stage in the differentiation of sex chromosomes (Ray-Chaudhury et al., 1971; Singh et al., 1976, 1980). Our results are consistent with this hypothesis and indicate that the differentiation of saurian sex chromosomes follows the same steps hypothesised for snakes. Clearly other species of the Lacertidae should be studied, particularly those possessing clearly heteromorphic sex chromosomes.

It has also been suggested that the first step of the sex-chromosomes differentiation is the storing up in one of the two sex-homologs of a specific satellite-DNA, linked with a heterochromatinisation process, and that these two events precede any morphological modification of this chromosome (Singh et al., 1980). This too should be examined in these lizards. 


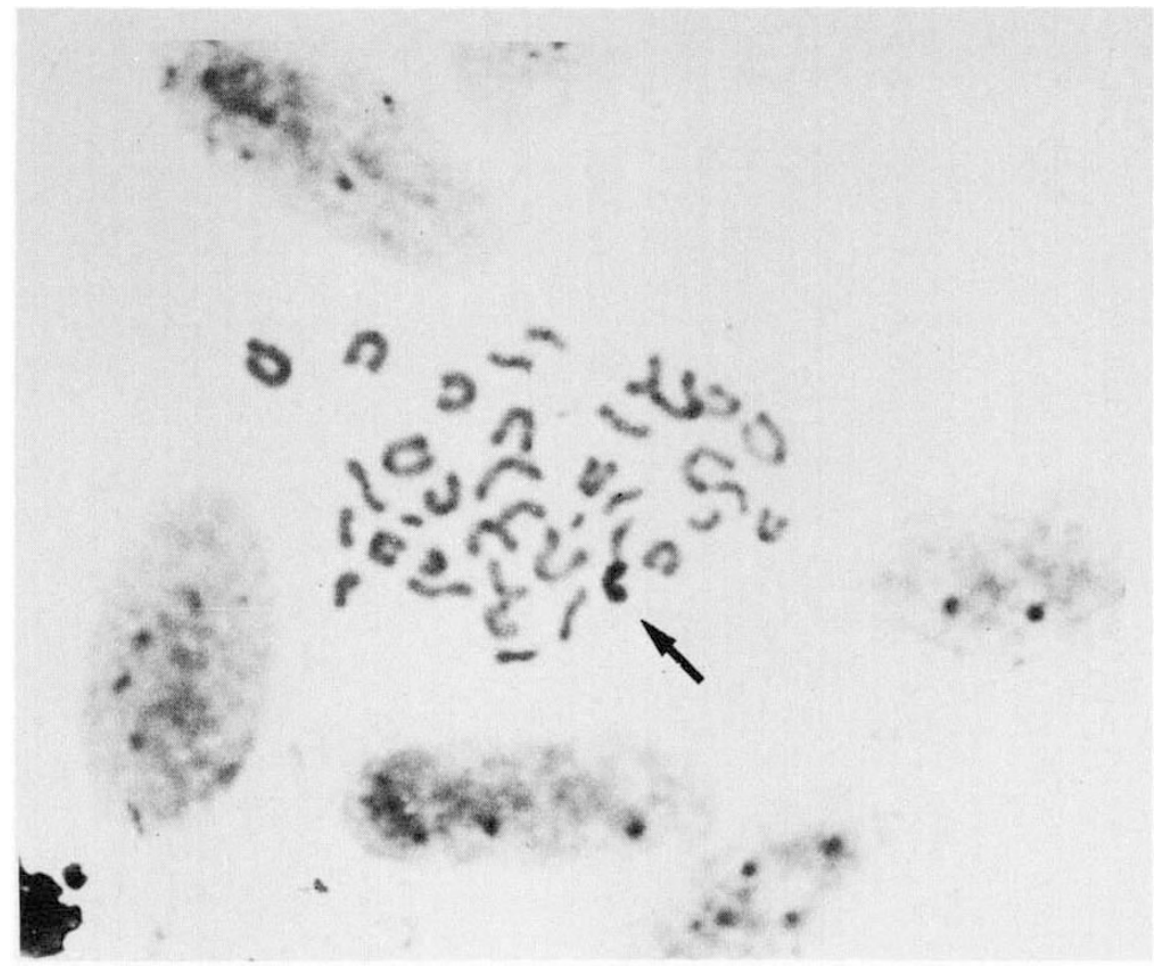

Plate 1. C-banded metaphase plate of a female Takydromus sexlineatus. The arrow indicates the heterochromatic W-chromosome.

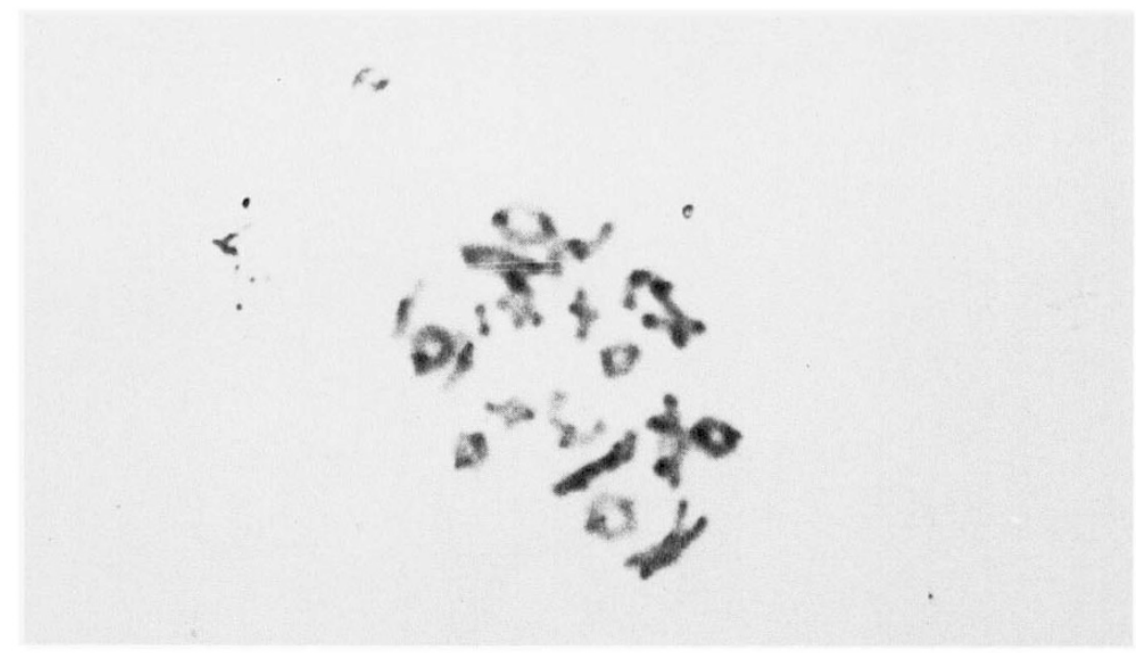

Plate 2. C-banded diplotene of a male Takydromus sexlineatus. Note that only the centromeres are C-banding positive. 


\section{REFERENCES}

BHATNAGAR, A. N. AND YONISS Y. TH. 1976 A proof of female heterogamety in a lacertid lizard. Ophisops elegans. Cytologia 41, 507-511.

BiCKHaM, J. w. 1983. Patterns and modes of chromosomal evolution in Reptiles. In Sharma, A. K. and Sharma, A. (eds.). Chromosomes in Evolution of Eukaryotic Groups. Vol. II. pp. $13-40$.

CHEVAlier. M. 1969. Données nouvelles sur le caryotype du lézard vivipare (Reptile, Lacertilien). Existe-t-il une hétérogametie femelle de type $\mathrm{Z}_{1} \mathrm{Z}_{2}$ W? $C$. R. Acad. Sci. Paris, $D$, 268, 2098-2100.

Chevalier, M., Dufaure, J. P. AND LeCher. P. 1979. Cytogenetic study of several species of Lacerta (Lacertidae, Reptilia) with particular reference to sex chromosomes. Genetica, $50,11-18$.

DAREVSKY, I. S. KUPRIYANOVA, L. A. AND BAKRADZE M. A. 1978. Occasional males and intersexes in parthenogenetic species of Caucasian rock lizards (genus Lacerta). Copeia 1978, 201-207.

DARLINGTON, C. D. AND LA COUR, L. F. 1969. The Handling of Chromosomes. 5th (ed.) George Allen \& Unwin, London.

DE SMET, W. H. O. 1981. Description of the orcein stained karyotypes of 36 lizard species (Lacertilia, Reptilia) belonging to the family Teiidae, Scincidae, Lacertidae, Cordylidae and Varanidae (Autarchoglossa). Acta Zool. et Pathol. Antverp, 76, 73-118.

GORMAN, G. C. 1969. New chromosome data for 12 species of lacertid lizards. J. Herpetol., 3, 49-54.

GORMAN, G. C. 1973. The chromosomes of the Reptilia, a cytotaxonomic interpretation. In Chiarelli, A. B. and Capanna, E. (eds.). Cytotaxonomy and Vertebrate Evolution. Academic Press, London and New York, pp. 349-424.

IVANOV, V. G., BOGDANOV, D. P., ANISIMOVA, E. YU. AND FEDOROVA, T. A. 1973. Studies of the karyotypes of three lizard species (Sauria, Scincidae, Lacertidae). Tsitologiya, 15, 1291-1296.

IVANOV, V. G. AND FEDOROVA, T. A., 1973. Heterochromosomes in the karyotype of Eremias arguta Pall. Tsitologiya, 15, 762-765.

JOHN, B. AND MIKLOS, G. L. G. 1979. Functional aspects of satellite-DNA and heterochromatin. Int. Rev. Cytol., 58, 1-114.

KUPRIYANOVA, L. A. 1968. Description of the karyotype of three species of Lacertidae family. Tsitologiya, 10, 892-895.

RAY-CHAUDHURY, S. P., SINGH, L. AND SHARMA, T. 1971. Evolution of sex-chromosomes and formation of W-chromatin in snakes. Chromosoma (Berl.), 33, 239-251.

SINGH, L., PURDOM, I. F. AND JONES, K. W. 1976. Satellite DNA and evolution of sex chromosomes. Chromosoma (Berl.), 59, 43-62.

SINGH, L., PURDOM, I. F. AND JONES, K. W. 1980. Sex chromosome associated satellite DNA: evolution and conservation. Chromosoma (Berl.), 79, 137-157.

SUMNER. A. T. 1972. A simple technique for demonstrating centromeric heterochromatin. Exp. Cell Res., 75, 304-306. 